\title{
Pengaruh Selebrity Endorsme, Brand Image, Dan Testimoni Dalam Menigkatkan Minat Beli Produk (Studi Kasus : Instagram UKM Kylafood)
}

\author{
Ogi Maulana Firli ${ }^{1}$, Muhamad Rizal $^{2}$, Ria Arifianti ${ }^{3}$, Asmaul Husna ${ }^{4}$ \\ ${ }^{123}$,Universitas Padjajaran, Bandung, Jawa Barat, Indonesia \\ Universitas Maritim Raja Ali Haji, Tanjungpinan, Kepulauan Riau, Indonesia
}

\begin{abstract}
The purpose of this study is to determine the effect of Celebrity Endorsement, Brand Image, and Testimonials on consumer buying interest in Kylafood products on Instagram Social Media. The research methods used in this research are descriptive and quantitative methods. Data analysis techniques and research model submissions use Structural Equation Modeling-Partial Least Square (SEM-PLS) with 95 questionnaire distribution data aimed at people who at least follow one celebrity endorsment on Instagram, know the kylafood brand, know the testimonials of the kylafood brand and intending to buy kylafood products. The results of this study state that the celebrity endorsement and testimonial variables have a significant positive effect on buying interest in Kylafood products on Instagram, while the brand image variable has a positive but not significant effect.
\end{abstract}

Keyword: Celebrity Endorsement, Brand Image, Testimonial, SME.

\begin{abstract}
ABSTRAK : Tujuan dari penelitian ini yaitu untuk mengetahui pengaruh Celebrity Endorsement, Brand Image, dan Testimoni terhadap minat beli konsumen produk kylafood di Media Social Instagram. Metode penelitian yang digunakan dalam peneltian ini yaitu metode deskriptif dan kuantitatif. Teknik analisis data dan pengajuan model penelitian menggunakan Structural Equation Modeling-Partial Least Square (SEM-PLS) dengan data penyebaran kuesioner sebanyak 95 responden yang ditujukan kepada masyarakat yang setidaknya mengikuti satu celebrity endorsment di Instagram, mengetahui merek kylafood, mengetahui testimoni dari merek kylafood dan berniat membeli produk kylafood. Hasil penelitian ini menyatakan bahwa variabel celebrity endorsement dan testimoni berpengaruh positif signifikan terhadap minat beli produk kylafood di Instagram, sementara pada variable brand image memiliki pengaruh positif tetapi tidak signifikan.
\end{abstract}

Kata Kunci: Celebrity Endorsement, Brand Image, Testimoni, UKM.

Email: Ogi2001@unpad.ac.id ${ }^{1}$, muhamad.rizal@unpad.ac.id ${ }^{2}$, ria.arifianti@unpad.ac.id ${ }^{3}$, asmaulhusna@umrah.ac.id ${ }^{4}$ 


\section{Pendahuluan}

Kehadiran teknologi informasi dalam pemasaran online semakin berdampak pada kehidupan manusia dalam hal memenuhi kebutuhannya. Karena kemudahan akses dan jangkauannya yang luas, siapapun dapat menelusuri berbagai situs dalam transaksi jual beli secara online. Keberadaan internet saat ini telah menjadi faktor penting dalam pekerjaan manusia di berbagai bidang karena memungkinkan manusia untuk mencari informasi dalam waktu yang relatif singkat. Alhasil, sangat menguntungkan bagi perusahaan untuk mendayagunakan teknologi ini untuk mendukung aktivitas perusahaan di masa depan, salah satunya adalah dengan membangun sosial media dalam kepentingan bisnisnya. Aziz (2018).

Media sosial merupakan salah satu teknologi popuper yang memiliki banyak penggunanya termasuk di Indonesia, hal tersebut dikatakan dalam laporan yang berjudul Digital 2021 : The latest insight in to the state of digital yang mengatakan sekitar 170 juta penduduk dari 274,9 juta total penduduk Indonesia atau sekitar $61,8 \%$ merupakan jumlah penduduk yang menggunakan media sosial. Adapun fungsi dari media sosial yaitu sebagai alat berkomunikasi secara digital yang juga bisa sekaligus dimamfaatkan sebagai alat pemasaran produk bagi pelaku bisnis dalam melakuan pemasaran produknya secara online.

Instagram merupakan salah satu jenis platform media sosial yang sering dijadikan sebagai lahan potensial untuk membuka lapak toko online. Hal tersebut banyak dimamfaatkan oleh para pelaku bisnis untuk menambah tempat jualan dan memperluas pasar dengan mempromosikan secara online di Instagram (putra,2020).

Penelitian ini bermaskud menganalisis variable pengaruh celebrity endorsement, brand image, dan testimoni terhadap minat beli produk. Endorsement merupakan salah satu sistem yang bisa dilakukan dalam pemasaran produk di Instagram dengan melakukan kerjasama dengan para artis Instagram atau yang akrab disapa selebgram. Celebrity Endorsement merupakan sebutan bagi seseorang yang memiliki kelebihan atau bakat yang banyak diterima dan diketahui oleh masyarakat luas, sehingga kisah atau perjalanan hidupnya bisa menjadi pengaruh bagi sebagian kelompok masyarakat. Murwaningtyas (2020). Selain endorsement, brand image dan testimonial atau ungkapan pelanggang mengenai produk dan pelayanan yang dilakulan oleh toko online yang terdapat di web atau media sosial (Awallia,2018) merupakan sistem lain dalam pemasaran produk yang dapat menarik perhatian pelanggan terhadap keputusan pembelian produk.

Kylood adalah salah satu UKM asal Bandung yang memamfaatkan Instagram sebagai lahan potensial dalam menjalankan strategi pemasaran penjualan produknya. Terhitung pada 1 Juni 2021 jumlah pengikut Kylafood di Instagram mencapai 333K followers. Berkat pengikut Instagramnya yang banyak, Kylafood mampu mendatangkan 1800 pembeli jumlah rata-rata setiap bulannya (Data:2020). Melihat hal tersebut, penulis memilih kylafood sebagai objek penelitian untuk mengetahui pengaruh Celebrity Endorsement, Brand Image, dan Testimoni terhadap minat beli produk pada toko online Kylood.

\section{Tinjauan Pustaka}

\section{Celebrity Endorsement}

Konsep selebriti secara umum dapat dijelaskan sebagai seseorang yang memiliki kelebihan professional dibidang kesenian dan penampilan yang lebih menarik yang diaku oleh publik dan dianggap sebagai panutan oleh masyarakat (McCraken, 1989), (Kahle dan Homer, 1985). Orang yang memiliki banyak pengikut yang banyak menginspirasi harapan, keinginan, dan impian konsumen (Rockwell \& Giles, 2009). Orang yang dikenal banyak orang yang juga dapat bertindak sebagai personifikasi merek, membangun ikatan dan hubungan dengan konsumen. Thomson (2006).

Terlepas dari dukungan aspek yang positif, menggunakan selebriti dalam sebuah kampanye akan menghasilkan dampak yang mungkin efektif atau mungkin kurang (Misra \& Beatty, 1990). Selebriti digunakan karena dianggap dapat mempengaruhi perilaku konsumen terhadap suatu porduk (Trripp et al., 1994) dan kampanye periklanan menciptakan 
hubungan antara produk dan selebriti yang dapat menyebabkan transfer makna yang dapat menjadi positif atau negative terhadap produk. Till dan Shimp (1998).

\section{Brand Image.}

Brand Image atau jika diartikan kedalam bahasa Indonesia adalah citra merek, definisi dari Brand Image itu sendiri yaitu sebuah persepsi yang muncul di benak konsumen saat mengingat suatu merek dari suatu produk. Anang (2019). Berikut merupakan beberapa pengertian tentang merek menurut para ahli:

Menurut Kotler \& Amstrong (2008) berpendapat bahwa merek merupakan sebuah nama, istilah, tanda, lambang, atau desain yang menggambarkan indentitas dari sebuah produk atau jasa untuk membedakan dengan produk atau jasa yang lainnya.

Menurut Ginting (2011) mendifinisikan merek adalah nama, istilah , tanda, lambang, atau desain untuk menandai produk atau jasa yang dapat membedakan produk atau jasanya dengan milik pesaing. Berdasarkan penjelasan diatas maka dapat disimpulkan bahwa merek itu merupakan nama, istilah, simbol, tanda, dan desain yang digunakan perusahaan sebagai sesuai hal yang membedakan dengan produk para pesaingnnya. Berikut merupakan beberapa pengertian citra merek dari beberapa sumber:

1. Citra merek merupakan seperangkat keyakinan konsumen mengenai merek tertentu. Kotler \& Amstrong (2001)

2. Citra merek merupakan beberapa kumpulan persepsi tentang sebuah merek yang saling berkaitan yang ada dalam fikiran manusia. Ouwersoot \& Tudorica (2001)

3. " Brand image can be defined as perception about brand as reflected by the brand association held in consumer memory". Atau dalam bahasa Indonesia berarti citra merek merupakan persepsi tentang merek yang digambarkan oleh asosiasi merek yang ada dalam ingatan konsumen Keller (1998).

\section{Testimoni}

Menurut Kotler \& Amstrong , berpendapat testimoni merupakan sumber materi iklan yang dapat diandalkan untuk mendukung produk tersebut. Testimoni merupakan suatu rekomendasi dari seseorang sehingga akan lebih efektif apabila konsumen itu sendiri yang memberi kesaksian mengenai ulasan yang ditawarkan. Dengan ini akan membantu menekan pesan pada ulasan iklan untuk lebih mudah di percaya konsumen. Setiawati (2015:15)

Menurut Griffith, berpendapat bahwa testimoni merupakan kegiatan dalam menciptakan kredibilitas, informasi yang dipublikasikan di sosial media harus memihak kepada masyarakat luas dibandingkan untuk kepentingan pribadi. Testimoni membantu konsumen untuk memutuskan menggunakan produk/jasa karena mendapatkan rekomendasi dari pihak ketiga dan hal itu akan bisa membuat lebih meyakinkan ketika ada seorang pelanggan yang sudah menggunakan produk/jasa yang membagi pengalamannya.

Menurut Kenneth Roman dan Jane Maas (2005), berpendapat bahwa testimoni merupakan sebuah cerita atau informasi yang diberikan dari seseorang yang telah berpengalaman menggunakan produk, dan ditampilkan sebagai bahan iklan. Berikut merupakan dampak yang akan dirasakan saat testimoni sampai pada calon pembeli menurut partao (2014) :

- Berkurang atau bahkan hilangnya rasa ragu untuk membeli.

- Berkurang atau bahkan hilangnya rasa takut akan resiko kerugian untuk membeli.

- Semakin meyakinkan calon pembeli untuk tidak ragu-ragu membeli sebuah produk.

\section{Minat Beli}

Menurut Kotler \& Keller (2016:137), berpendapat bahwa minat beli merupakan salah satu jenis perilaku konsumen yang muncul sebagai tanggapan terhadap objek yang menunjukan keinginan seseorang untuk membeli sesuatu. Sementara Sciffman \& Kanuk (2015:228) juga berpendapat bahwa 
minat beli merupakan gambaran sikap seseorang terhadap objek yang sangat cocok untuk mengukur perilaku produk, jasa, atau merek tertentu. Nulifi \& Murwatiningsih (2015) juga berpendapat bahwa minat beli merupakan sikap positif yang dimiliki konsumen terhadap suatu produk atau merek, yang akan menimbulkan pembelian terhadap produk atau merek tersebut.

Berikut merupakan indikator minat beli seseorang dalam memutuskan pembelian menurut Suwandari (2008) :

1. Attention, yaitu tahap seorang calon pembeli menilai dan mempelajari suatu produk yang ditawarkan.

2. Interst, ketertarikan calon pembeli terhadap produk yang ditawarkan, sehingga munculnya hasrat rasa ingin memiliki sudah mulai timbul.

3. Desire, yaitu tahap dimana calon pembeli memikirkan untuk memutuskan pembelian terhadap produk yang ditawarkan dengan perasaan semakin ingin memiliki.

4. Action, yaitu tahap seorang calon pembeli sudah mantap memutuskan. untuk membeli produk atau merek yang telah diperhatikan tersebut

\section{Metode penelitian.}

Populasi menurut Sugiyono (2007:72) : "adalah wilayah generalisasi yang terdiri atas obyek atau subyej yang mempunyai kualitas dan karakteristik tertentu yang ditetapkan oleh peneliti untuk dipelajari dan kemudia ditarik kesimpulannya". Populasi penelitian ini adalah para masyarakat yang pernah mengonsumsi produk kylafood. Adapun jumlah sampe yang digunakan sebanyak 95 responden, yang setidaknya mengikuti satu celebrity endorment di Instagram, mengetahui merek kylafood, mengetahui testimoni dari merek kylafood dan berniat membeli produk kylafood.

Jenis penelitian yang dilakukan adalah deskriptif kuantitatif, deskriptif kuantitatif adalah jenis penelitian yang digunakan untuk menganalisis data dengan cara mendeskripsikan data yang telah terkumpul sebagaimana adanya. Fauziah (2018). Data yang dikumpulkan pada penelitian ini merupakan data primer berupa penyubaran kuesioner serta data sekunder dengan melalukan studi Pustaka dan literatur.

\section{Tabel 1. Faktor Loading}

\begin{tabular}{|c|c|c|c|c|} 
& Celebrity Endorsement & Brand Image & Testimoni & Minat Beli \\
\hline $\mathrm{X} 1.1$ & 0,834 & & \\
\hline $\mathrm{X} 1.2$ & 0,87 & & \\
\hline $\mathrm{X} 1.3$ & 0,642 & & \\
\hline $\mathrm{X} 1.4$ & 0,792 & & \\
\hline $\mathrm{X} 1.5$ & 0,923 & & \\
\hline $\mathrm{X} 2.1$ & & 0,846 & \\
\hline $\mathrm{X} 2.2$ & & 0,861 & & \\
\hline $\mathrm{X} 2.3$ & & 0,908 & & \\
\hline $\mathrm{X} 2.4$ & & 0,896 & & \\
\hline $\mathrm{X} 2.5$ & & 0,873 & & \\
\hline $\mathrm{X} 3.1$ & & & 0,689 & \\
\hline $\mathrm{X} 3.2$ & & & 0,719 & \\
\hline $\mathrm{X} 3.3$ & & & 0,772 & \\
\hline $\mathrm{X} 3.4$ & & & 0,852 & \\
\hline $\mathrm{X} 3.5$ & & & 0,879 & \\
\hline $\mathrm{Y} 1.1$ & & & & 0,748 \\
\hline $\mathrm{Y} 1.2$ & & & & \\
\hline $\mathrm{Y} 1.3$ & & & & \\
\hline $\mathrm{Y} 1.4$ & & & & \\
\hline $\mathrm{Y} 1.5$ & & & & \\
\hline & & & & \\
\hline & & & & \\
\hline
\end{tabular}

Sumber: Data diolah (2021)

Hasil uji validitas dan reliabilitas disajikan sebagai berikut. Faktor loading merupakan nilai yang dimiliki oleh setiap indikator, nilai tersebut akan dianggap valid jika bernilai diatas 0,7.hasil dari pengujian faktor loading diatas menyatakan bahwa indikator-indikator tersebut memiliki nilai diatas 0,7 sehingga indikator tersebut dikatakan valid. AVE atau merupakan kependekan dari Average Variance Extracted (AVE) merupakan nilai yang dimiliki oleh setiap variabel. Nilai yang berjumlah diatas 0,5 maka dianggap valid hasilnya. Berikut adalah hasil dari olah data AVE :

Tabel 2. Average Variance Extracted (AVE)

\begin{tabular}{|l|c|c|}
\hline \multicolumn{1}{|c|}{ Variabel } & AVE & Keterangan \\
\hline Celebrity Endorsement (X1) & 0,796 & Valid \\
\hline Brand Image (X2) & 0,699 & Valid \\
\hline Testimoni (X3 & 0,737 & Valid \\
\hline Minat Beli (Y1) & 0,618 & Valid \\
\hline
\end{tabular}

Sumber: Data diolah (2021)

Hasil dari pengujian AVE untuk variabel celebrity endorsement, brand image, testimoni dan variabel minat beli menunjukan 
nilai AVE di atas 0,5 atau sama dengan dapat dikatakan bahwa secara keseluruhan variabel dalam penelitian ini validitasinya terpenuhi. Reabilitas konstruk diukur dengan menggunakan nilai composite reliabity. Konstruk akan dianggap reliabel jika nilainya berada diatas 0,70 . Hasil pengukuran konstruk menggunakan composite reliabity menghasilkan nilai berada diatas 0,70 sehingga dapat dikatakan bahwa konstruk ini dikatakan reliabel.

Tabel 3. Cronbach's Alpha

\begin{tabular}{|l|c|}
\multicolumn{1}{c|}{ Variable } & Cronbach's Alpha \\
\hline Celebrity Endorsement (X1) & 0,925 \\
\hline Brand Image (X2) & 0,874 \\
\hline Testimoni (X3) & 0,908 \\
\hline Minat Beli Konsumen (Y1) & 0,846
\end{tabular}

Sumber: Data diolah (2021)

\section{Uji Hipotesis}

Pengujian hipotesis di SEM SmartPLS dilakukan dengan bootstrapping menghasilkan koefisien dan nilai T-statistic, berikut adalah tabel yang berisi hasil uji hipotesis:

\section{Tabel 4. Uji Hipotesis}

\begin{tabular}{|c|l|c|c|c|c|c|}
\hline No & Hipotesis & $\begin{array}{c}\text { Sampel } \\
\text { Asli }\end{array}$ & $\begin{array}{c}\text { Rata- } \\
\text { Rata } \\
\text { Sampel }\end{array}$ & $\begin{array}{c}\text { Standar } \\
\text { Deviasi }\end{array}$ & $\begin{array}{c}\mathrm{T} \\
\text { Statistic }\end{array}$ & $\begin{array}{c}\mathrm{P} \\
\text { Value }\end{array}$ \\
\hline 1 & $\begin{array}{l}\text { Celebrity } \\
\text { Endorsement } \\
\text { (X1) }\end{array}$ & 0,506 & 0,502 & 0,133 & 3,817 & 0 \\
\hline 2 & $\begin{array}{l}\text { Brand Image } \\
(\mathrm{X} 2)\end{array}$ & $-0,199$ & $-0,197$ & 0,146 & 1,368 & 0,172 \\
\hline 3 & $\begin{array}{l}\text { Testimoni } \\
(\mathrm{X} 3)\end{array}$ & 0,565 & 0,573 & 0,094 & 5,993 & 0 \\
\hline
\end{tabular}

Sumber: Data diolah (2021)

Berdasarkan Tabel, diperoleh hasil bahwa hipotesis $\mathrm{H} 1$, dan $\mathrm{H} 3$ memiliki nilai di bawah taraf signifikan 5\%, sehingga hasil uji hipotesis memiliki pengaruh positif dan signifikan terhadap variabel dependen. Sedangkan untuk $\mathrm{H} 2$ hanya memiliki pengaruh positif tetapi tidak signifikan karena nilai $\mathrm{p}$-valuesnya berjumlah diatas $5 \%$ yaitu sebesar $17,2 \%$.

Faktor yang membuat $\mathrm{H} 1$ atau variabel Celebrity Endorsement memiliki pengaruh positif dan signifikan yaitu nilai P-values yang dihasilkan berjumlah dibawah 5\% yaitu senilai 0.000 , hal tersebut dikarekan kylafood sering sekali menggunakan jasa promosi atau bekerjasama dengan Celebrity Endorsement yang namanya sudah besar, salah satu dari sekian banyak celebrity tersebut yaitu Rachel Vennya seorang pengusaha bidang kuliner yang sukses yang membuat Rachel terkenal dan sering menginfluce banyak orang, followers Rachel Vennya pada tanggal 13 April 2021 mencapai 5,4M hal tersebut dikarenakan konten yang dibuat Rachel selalu menarik perhatian, Rachel merupakan seorang ibu muda yang sering membagikan kegiatan sehari-harinya di Instagram, salah satu kegiatan yang sering diunggah oleh ibu muda dua anak ini yaitu memasak dan memakan makanan yang enak. Sehingga saat kylafood bekerjasama dengan Rachel produk yang ditayangkan sudah dimasak dan disajikan dengan sangat menarik, dan apa yang dimakan dan diucapkan oleh Rachel selalu mempengaruhi banyak orang untuk mau melakukan hal yang sama.

Faktor yang membuat $\mathrm{H} 2$ atau variabel Brand Image memiliki pengaruh positif tetapi tidak signifikan karena nilai P-values pada $\mathrm{H} 2$ berjumal diatas 5\% yaitu sebesar 17,2\% hal tersebut dikarenakan lemahnya hasil dari uji coba pada indikator X2.1 atau sama dengan masih kurang melekatnya dalam fikiran masyarakat bahwa seblak instant sehat itu merupakan produk kylafood.

Faktor yang membuat $\mathrm{H} 3$ atau variabel Celebrity Endorsement memiliki pengaruh positif dan signifikan yaitu nilai $\mathrm{P}$-values yang dihasilkan berjumlah dibawah $5 \%$ yaitu senilai 0.000 , hal tersebut dikarenakan kylafood banyak mendapatkan testimoni baik dan terpercaya dari konsumennya yang dibagikan di sosial media Instagram.

\section{Kesimpulan}

Berdasarkan hasil dari penelitian yang telah diuraikan diatas, maka penelitian ini dapat disimpulkan sebagai berikut:

1. Variabel Celebrity Endorsement berpengaruh positif dan signifikan terhadap minat beli konsumen pada 
produk Kylafood. Salah satu faktor yang membuat variabel ini positif dan signifikan karena Kylafood sering bekerjasama dengan Celebrity Endorsement yang namanya sudah besar/terkenal.

2. Variabel Brand Image berpengaruh positif tetapi tidak signifikan terhadap minat beli konsumen pada produk Kylafood. Hal tersebut karena ada satu indikator yang hasilnya masih cukup lemah dalam uji coba penelitian ini.

3. Variabel Testimoni berpengaruh positif dan signifikan terhadap minat beli konsumen pada produk Kylafood. Hal tersebut dikarenakan Kylafood selalu mendapatkan testimoni baik dari konsumennya yang dibagikan di media sosial Instagram.

\section{Daftar Pustaka}

Adila, S. N., \& Aziz, N. (2019). Pengaruh Strategi Promosi terhadap Keputusan Pembelian yang dimediasi oleh minat beli pada konsumen Restoran KFC cabang khatib Sulaiman Padang

Awallia, D. L. (2018). Pengaruh Testimoni dan Selebgram Endorsement Terhadap Minat Pembelian pada Online Shop Melalui Media Sosial Instagram Mahasiswa Fakultas Syariah IAIN Ponorogo. Skripsi.

Aziz, E. S. N., \& Yanto, H. (2018, August). Perancangan Aplikasi Penjualan Berbasis Web Pada Branded Thrift Shop Pontianak. In ENTER (Vol. 1, No. 1, pp. 492-503).

Bakti, U. (2020). Pengaruh Kualitas Pelayanan, Produk dan Harga Terhadap Minat Beli Pada Toko Online Lazada di Bandar Lampung. Jurnal Ekonomi, 22(1), 101-118.

Dr. M. Anang Firmansyah, SE, MM. "pemasaran produk dan merek", 5 agustus 2019, Penerbitan Qiara Media.

Fauziah, A. A. (2018). Hubungan antara budaya sekolah dengan mutu sekolah di
sma muhammadiyah 18 sunggal (Doctoral dissertation, Universitas Negeri Islam Sumatra Utara).

Fauziyah, F. (2020). Tantangan UMKM Dalam Menghadapi Revolusi Industri 4.0 Ditinjau Dari Aspek Marketing Dan Accounting. (JMK) Jurnal Manajemen dan Kewirausahaan, 5(2), 155-172.

Freire, O., Quevedo-Silva, F., \& Scrivano, D. S. (2018). The effectiveness of celebrity endorsement in aspiring new celebrities: Examining the effects of brand, congruence, charisma and overexposure. RAUSP Management Journal, 53(3), 289-303.

Jalinus, N., \& Risfendra, R. (2020). Analisis Kemampuan Pedagogi Guru SMK yang sedang Mengambil Pendidikan Profesi Guru dengan Metode Deskriptif Kuantitatif dan Metode Kualitatif. INVOTEK: Jurnal Inovasi Vokasional dan Teknologi, 20(1), 37-44.

Kurniawan, G. (2020). Pengaruh Celebgram Dan Brand Image Terhadap Minat Beli Konsumen Secara Online Pada Media Sosial Instagram Produk Erha Clinic Di Surabaya. Jurnal MEBIS (Manajemen dan Bisnis), 5(1), 39-47.

Murwaningtyas, F., Harisudin, M., \& Irianto, H. (2020). Effect of Celebrity Endorser Through Social Media on Organic Cosmetic Purchasing Intention Mediated with Attitude. KnE Social Sciences, 152165.

Partao, Z. A. (2014). TESTIMONIAL: Ketika Pelanggan Anda Jadi Ujung Tombak Tenaga Marketing \& Penjualan yang Paling Militan. Alaz Self Publishing.

Utama, R. D. H., \& Rosalina, F. (2016). Pengaruh Testimoni dalam Periklanan. Manajerial: Jurnal Manajemen dan Sistem Informasi, 15(1), 97-117.

Saputro, A. A., Hidayati, N., \& Rizal, M. (2020). Pengaruh Celebrity Endorsement, Testimoni, dan Keamanan 
terhadap Keputusan Pembelian Pada Online Shop Blibli. com (Studi Pada Mahasiswa FEB Unisma Angkatan Tahun 2016). Jurnal Ilmiah Riset Manajemen, 9(16).

Shahnaz, N. B. F., \& Wahyono, W. (2016). Faktor Yang Mempengaruhi Minat Beli Konsumen Di Toko Online. Management Analysis Journal, 5(4).

Solihin, D. (2020). Pengaruh Kepercayaan Pelanggan dan Promosi Terhadap Keputusan Pembelian Konsumen Pada Online Shop Mikaylaku Dengan Minat Beli Sebagai Variabel Intervening. JURNAL MANDIRI: Ilmu Pengetahuan, Seni, dan Teknologi, 4(1), 38-51.

Tajri, M. A., \& Nada, N. Q. (2019, December). SISTEM TESTIMONIAL PELANGGAN UNTUK MENINGKATKAN PROMOSI PENJUALAN LAYANAN PADA PERUSAHAAN STAR SHARE BERBASIS WEBSITE. In Seminar Nasional Science and Engineering National Seminar (Vol. 1, No. 1).

Rukajat, A. (2018). Pendekatan penelitian kuantitatif: quantitative research approach. Deepublish.

Wikatanazal, E., Pardiman, P., \& Rizal, M. (2021). Pengaruh Celebrity Endorser Dan Iklan Instagram Terhadap Keputusan Pembelian (Studi Kasus Pada Online Shop Championsteall. Id). Jurnal Ilmiah Riset Manajemen, 10(4).

Wuisan, D., Kananda, I. L., Saputra, M. A., \& Dinata, M. R. (2020). The Effect of Celebrity Endorsement on Purchase Intention of Adidas Products Mediated by Customer's Attitude Toward Brand. In Conference Series (Vol. 3, No. 1, pp. 525-533). 